Selcuk Journal of Agriculture and Food Sciences

$\underline{\text { http://sjafs.selcuk.edu.tr/sjafs/index }}$

Research Article
SJAFS

(2020) 34 (1), 70-77

e-ISSN: $2458-8377$

DOI:10.15316/SJAFS.2020.197

\title{
Maintenance of Physicochemical Qualities of Nectarine Fruits During Cold Sto- rage Using Ultrasonic Treatment with Salicylic Acid
}

\author{
Erdinç BAL ${ }^{1}$ \\ ${ }^{1}$ Tekirdağ Namık Kemal University, Faculty of Agriculture, Department of Horticulture, Tekirdağ, Turkey
}

\begin{tabular}{l}
\hline ARTICLE INFO \\
\hline Article history: \\
Received date: 24.10 .2019 \\
Accepted date: 06.02 .2020 \\
\hline Edited by: \\
Ali SABIR; Selçuk University, Turkey \\
Reviewed by: \\
Aşkın BAHAR; Selçuk University, Tur- \\
key \\
İhsan CANAN; Bolu Abant İzet Baysal \\
University, Turkey \\
\hline Keywords: \\
Nectarine \\
Ultrasonic \\
Salicylic acid \\
Biochemical compound \\
Chilling injury
\end{tabular}

\section{Introduction}

Peaches and nectarines are similar genetically and horticulturally, but for commercial purposes are regarded as two different fruits. The nectarine is essentially a fuzzless peach (Brown et al 1983). Nectarine is high functional fruits as a consequence of their bioactive compounds and deteriorate rapidity at ambient temperature. Therefore, cold storage of nectarines after harvest is necessary to minimize excessive softening, quality loss and decay and to prolong time for marketing (Celik et al 2006). Nectarines as climacteric stone fruits have a limited post-harvest life and they remain fresh only for 2-6 weeks stored at $0^{\circ} \mathrm{C}$ and $90-95 \%$ relative humidity depending on cultivar (Karen 1991).

After harvest, the nutritional and organoleptic quality of fresh produce start to decline as a result of altered plant metabolism. Quality deterioration of fruits is the result of produce transpiration, senescence, ripening associated processes and development of postharvest disorders (Kader 2001). However, the most important factor that limits the post-harvest life of nectarine is chilling injury (CI) or internal breakdown (Candir et al 2009). Fruits stored between $2.2^{\circ} \mathrm{C}$ and $7.6^{\circ} \mathrm{C}$ are

\footnotetext{
* Corresponding author email: ebal@nku.edu.tr
}

more prone to chilling injury than those stored at $0^{\circ} \mathrm{C}$ or lower (Crisosto et al 1999). Therefore, it is very important to prevent the postharvest losses of nectarine fruit.

Salicylic acid (SA), the plant natural organic compounds which is found in a wide range of plant species, has been reported to play a vital role in regulating plant growth and development. Moreover, this compound have been proven to be photochemical inducing bioactive compounds such as antioxidants and antioxidant enzymes and have been use for maintaining postharvest quality of perishable commodities (Supapvanich\&Promyou 2013).

SA induces hydrogen peroxide $\left(\mathrm{H}_{2} \mathrm{O}_{2}\right)$ accumulation at high temperatures while reducing $\mathrm{H}_{2} \mathrm{O}_{2}$ at lower temperatures. During chilling stress, the activities of antioxidant enzymes are decreased, which leads $\mathrm{H}_{2} \mathrm{O}_{2}$, and other reactive oxygen species. SA is involved in chilling tolerance through $\mathrm{H}_{2} \mathrm{O}_{2}$ metabolism mediation. (Kang et al 2003). SA has also been reported to reduce spoilage in peach fruit by controlling cell membrane electrolyte leakage, decreasing respiration and ethylene production, maintaining flesh firmness, and increasing antioxidant enzymes activities (Han et al 2003). In recent years, exogenous application of SA has been reported to improve storage life and storage quality 
attributes in many fruit like peach (Tareen et al 2012; Awad 2013), plum (Sabir 2017), apricot (Ezzat et al 2017).

Increasing public demands for improved safety and quality of fruits and vegetables in the fresh market, awaken a growing interest for novel technologies for the preservation of postharvest fruits and vegetables before storage. Ultrasonic technology provides one of the methods that with better treating time, enhanced products quality, reduced chemical hazards, low consumption of energy, and is environmentally friendly (Yuting et al 2013). Ultrasonic is composed of mechanical sound waves that originate from molecular movements that oscillate in a propagation medium (Gallo et al 2018). Postharvest ultrasonic treatments (UT) have been shown to extend shelf life and maintain quality in strawberries (Aday\&Caner 2014), litchis (Chen et al 2012), pears (Zhao et al 2007), and plums (Chen\&Zhu 2011). In addition, there are various reports indicating that combination of ultrasonic and other chemicals effectively increased postharvest life of horticultural crops (Chen\&Zhu 2011; Yang et al 2011, Bal 2013; Bal 2016; Bal et al 2017, Khademi et al 2019). However, there is no study on the combined effects of ultrasonic with SA treatment on quality controlling in postharvest nectarine fruit. Thus the purpose of this study was to investigate the ability of ultrasonic treatment with SA to maintain physicochemical qualities and alleviate CI of nectarine fruits during cold storage.

\section{Materials and Methods}

Nectarine (Prunus persica var. nectarina) cv. 'Venus' fruits were harvested manually at firm-ripe stage (firmness was about $75 \mathrm{~N}$; SSC was about 12.7\%) from a commercial orchard in Turkey and immediately transported to the postharvest physiology laboratory. Fruits were selected for similar size, uniform maturity and appearance and freedom from defects.

\section{Treatments and Storage Conditions}

Ultrasonic treatment was applied in sonicator bath with water $\left(20^{\circ} \mathrm{C}\right)$ in the ultrasonic chamber. Fruits were treated with $32 \mathrm{kHz}$ ultrasonic at powers of 60 $\mathrm{W}^{*} \mathrm{~L}^{-1}$ for $10 \mathrm{~min}$ in $10 \mathrm{~L}$ distilled water. A surfactant Tween $20^{\circledR}$ at $1 \mathrm{~g}^{*} \mathrm{~L}^{-1}$ was also added to enhance infiltration. SA concentrations of $1 \mathrm{mM}$ and $2 \mathrm{mM}$ were prepared by dissolving SA powder (Sigma Aldrich Co.) in hot distilled water. Fruits were divided into four groups. Treatments and abbreviations can be summarized as follows:

1. Control: Fruits was immersed in distilled water at $20^{\circ} \mathrm{C}$ for $10 \mathrm{~min}$

2. Ultrasonic treatment (UT): Fruits was immersed (distilled water) in sonicator bath at $20^{\circ} \mathrm{C}$ for $10 \mathrm{~min}$

3. SA1 treatment: Fruits was immersed in sonicator bath at $1 \mathrm{mM} \mathrm{SA}$ and $20^{\circ} \mathrm{C}$ for $10 \mathrm{~min}$

4. SA2 treatment: Fruits was immersed in sonicator bath at $2 \mathrm{mM} \mathrm{SA}$ and $20^{\circ} \mathrm{C}$ for $10 \mathrm{~min}$
5. Ultrasonic treatment with SA1: Fruits was immersed in sonicator bath at $1 \mathrm{mM} \mathrm{SA}$ and $20^{\circ} \mathrm{C}$ for $10 \mathrm{~min}$ 6 . Ultrasonic treatment with SA2: Fruits was immersed in sonicator bath at $2 \mathrm{mM} \mathrm{SA}$ and $20^{\circ} \mathrm{C}$ for $10 \mathrm{~min}$

After dipping treatments, fruit placed on craft paper were allowed to dry at room temperature for approximately $60 \mathrm{~min}$. Dried nectarines were placed in plastic boxes and stored at $0^{\circ} \mathrm{C}$ and $90 \pm 5 \%$ relative humidity for 60 days. During storage, 10 fruit of each replicate were analyzed at 15 days intervals. Other group of 20 fruit was used for initial analyses.

\section{Analysis of Quality Attributes}

Weight loss of nectarines was expressed as the percentage of loss of weight with respect to the initial weight (\%). Firmness was determined using a hand penetrometer with an $8 \mathrm{~mm}$ long measuring plunger and was expressed as Newton (N).

For the analysis of soluble solids content (SSC) and titratable acidity (TA) of each sample, tissue sap was squeezed out from fresh fruit materials with a press. In this juice, SSC were determined with a hand refractometer (\%). TA content was determined by titrating method and calculating the result as grams of malic acid per $100 \mathrm{~g}$ fresh weight (\%).

Ascorbic acid content of the samples was determined according to the recommended method of A.O.A.C. (2000) using 2,6-dichlorophenol indophenol and expressed as $\mathrm{mg} \mathrm{kg}^{-1}$.

The total flavonoid contents were measured by a colorimetric assay (Zhishen et al 1999) and the results were expressed as $\mathrm{mg}$ (rutin equivalent) $100 \mathrm{~g}^{-1}$. Total phenolics of the nectarine extract were quantified spectrophotometrically using Folin-Ciocalteu reagent based on the method (Slinkard\&Singleton 1977). Results were expressed as mg (gallic acid equivalent) 100 $\mathrm{g}^{-1}$.

Total antioxidants was determined by 2, 2diphenyl-1-picrylhydrazyl (DPPH) free radicalscavenging method as described by Brand-Williams et al (1995) and was expressed as $\mu \mathrm{mol}$ (trolox equivalent) $\mathrm{g}^{-1}$.

For evaluation of CI, nectarine fruits were longitudinally cut into halves for the evaluation of the occurrence of CI according to the severity of exocarp browning and flesh translucency (Khan et al 2011). CI was estimated visually as the percentage of the affected area compared with the total surface area of each section on a scale where: $0=$ no change; $1=$ less than $10 \% ; 2=10-25 \% ; 3=25-50 \% ; 4=50-75 \%$; and $5=$ more than $75 \%$.

The experiment was set up according to the factorial randomized design with 3 replications (10 fruit per replication). Analysis of Variance was the means for analyzing the difference between means and while LSD test being applied for mean separation at $p<0.05$. All the analyses were carried out through SPSS as statistical software. Data were expressed as the mean \pm SE for all parameters. 


\section{Results and Discussion}

\section{Weight loss}

Weight loss is a major factor reflecting the quality of fruit. Weight loss of nectarine fruit constantly increased during whole storage duration due especially to respiration and transpiration process, regardless of the treatments (Figure 1). Ultrasonic treatment alone did not affect weight loss of fruit. However, combined treatment with ultrasonic and SA showed significantly reduced loss of weight, than control. UT + SA1 and UT + SA2 treatments reduced weight loss of fruits. At the end of the storage, the highest weight loss was determined in ultrasonic treated fruits $(6.9 \%)$ and control fruits $(6.6 \%)$, while the lowest weight loss was determined in UT + SA2 treatment $(5.2 \%)$ followed by UT + SA1 treatment $(5.3 \%)$. The anti-senescent action and maintenance of cellular integrity by SA in the present study might be the reason in lowering weight loss of nectarine (Bal 2016; Ezzat et al 2017). These findings for SA were supported on different fruit crops (Srivastava\&Dwivedi 2000; Zheng\&Zhang, 2004). Moreover, salicylic acid as an electron donor produces free radicals which prevents normal respiration (Wolucka et al 2005) and can also decrease respiration rate and fruit weight loss by stoma closing (Zheng\&Zhang, 2004).

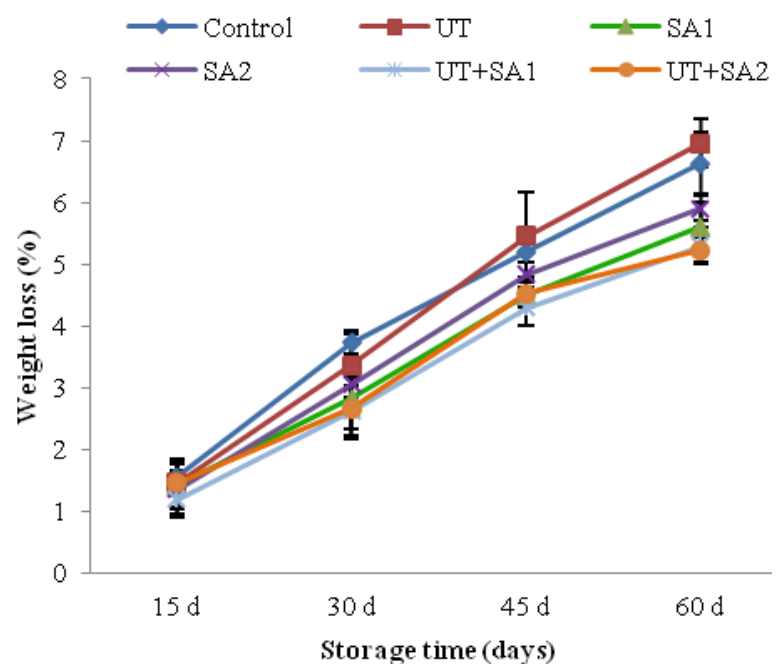

Figure 1

Effect of ultrasonic and salicylic acid treatments on weight loss of nectarine fruit during storage

\section{SSC and TA}

SSC and TA were assessed as indicators of the metabolic activity and ripening stage of the fruit. In the study, While TA decreased gradually during storage with no significant differences between the treatments, a significant increase in SSC was observed (Figure $2,3)$. A similar increase in SSC during storage of nectarine fruit has been previously reported (Ozdemir et al 2006; Bal 2018). Increases in SSC usually accompany with ripening of climacteric fruits. At the end of storage, the highest SSC value was determined in control fruits $(15 \%)$, while the lowest SSC value was determined in UT + SA2 treatment (13.4\%). Comparing with the control fruit, UT + SA2 treatment retarded SSC increase of nectarine fruit, effectively maintaining the initial quality. These results are in accordance with those obtained by Erbas et al (2015) and Sabir (2017) who showed that SSC increased slightly with SA treatments during storage.

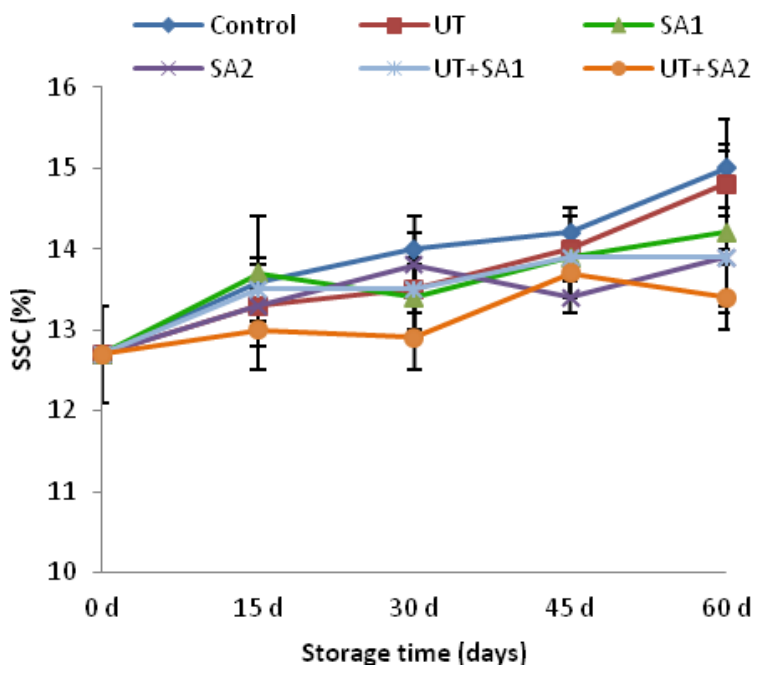

Figure 2

Effect of ultrasonic and salicylic acid treatments on SSC and TA of nectarine fruit during storage

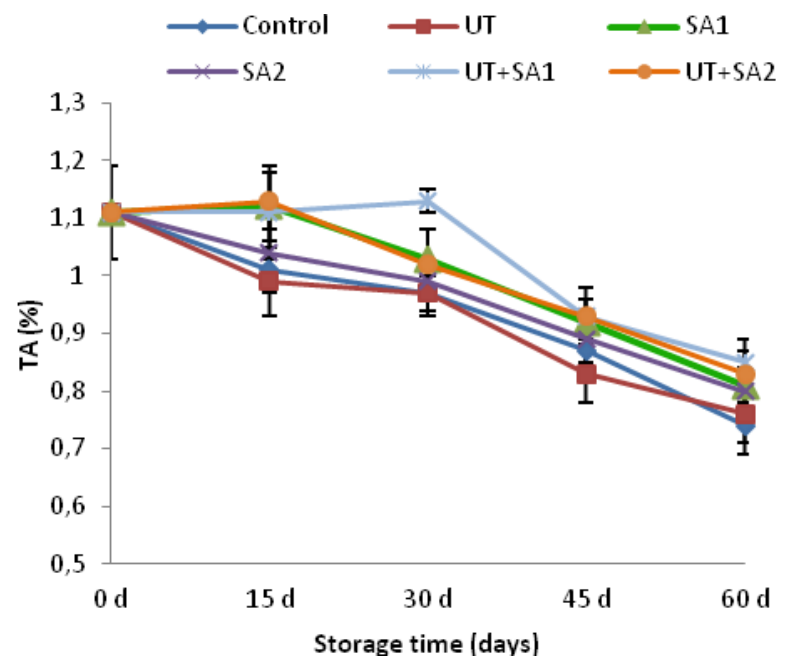

Figure 3

Effect of ultrasonic and salicylic acid treatments on SSC and TA of nectarine fruit during storage

\section{Fruit firmness}

Fruit softness occurs as a result of deterioration in cell wall structures and changes in cellulose and pectin components. In the study, nectarine firmness decreased during postharvest storage due to softness of fruit tissues via metabolic changes induced by enzymatic action and respiration (Figure 4). Firmness value of nectarine fruits at harvest time was $75.3 \mathrm{~N}$. In control and ultrasonic treatment, fruit firmness value decreased to $45 \mathrm{~N}$ during 60 day cold storage. At the end of the storage, the highest firmness was determined in UT + SA2 treatment $(58 \mathrm{~N})$, followed by SA2 $(54.6 \mathrm{~N}), \mathrm{UT}+$ SA1 treatment $(53.3 \mathrm{~N})$ and SA1 treatment $(50 \mathrm{~N})$, 
respectively. Ultrasonic alone had no influence, but when it was combined with SA, it resulted in greater retardation of firmness softening than SA alone. This is in agreement with Yuting et al (2013) and Bal et al (2017) who reported that ultrasonic could facilitate polyamine penetration into the tissue cells of fruits; a quicker and stronger resistance is induced. Moreover, delayed ripening process in SA treated fruits was concentration dependant and $2 \mathrm{mM}$ SA dose maintained the firmness better than $1 \mathrm{mM}$ SA. Higher firmness in SA alone or combination treated fruits might be attributed to the reduced hydrolysis of soluble starch. Increased retention of firmness as the result of SA treatment has also been reported in several horticultural crops (Srivastava\&Dwivedi 2000; Zhang et al 2003; Asghari\&Aghdam 2010).

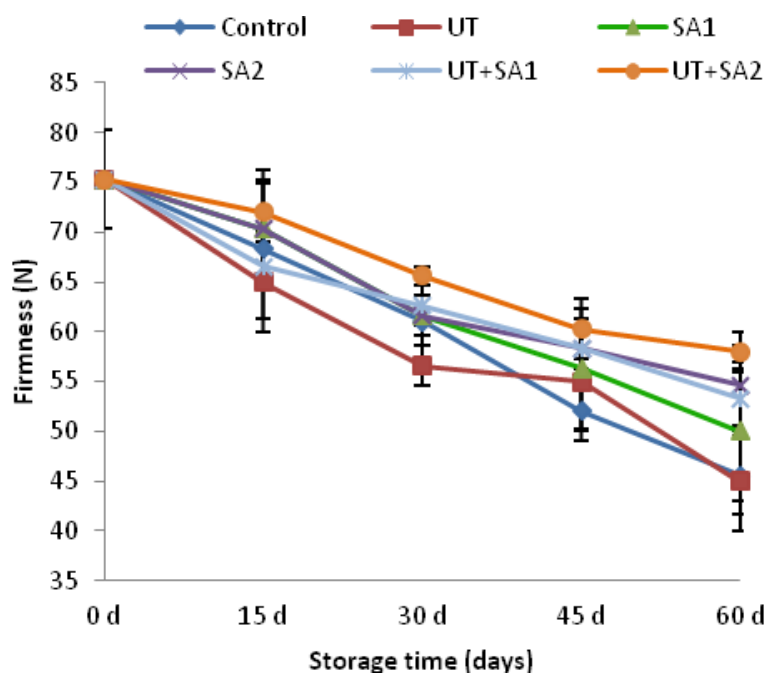

Figure 4

Effect of ultrasonic and salicylic acid treatments on firmness of nectarine fruit during storage

\section{Ascorbic acid}

Ascorbic acid is an important nutrient quality parameter and is very sensitive to degradation due to its oxidation compared to other nutrients during food processing and storage (Veltman et al 2000). The variation on ascorbic acid content is indicated in Figure 5. The content of ascorbic acid dropped notably during the storage of 40 days in all the samples. These results are consistent with previous reports showing that the levels of ascorbic acid in peaches, nectarines and apricots increased soon after harvest and decreased during storage (Lee\&Kader 2000; Zhao et al 2018). The application of UT + SA2 and SA2 treatment significantly slowed the falling tendency. After 60 days of storage, the lowest ascorbic acid value was determined in ultrasonic treated fruits $\left(161 \mathrm{mg} 100 \mathrm{~g}^{-1}\right)$ followed by control fruits (175 $\left.\mathrm{mg} 100 \mathrm{~g}^{-1}\right)$, while the highest ascorbic acid value was determined in UT + SA2 treated fruits $\left(205 \mathrm{mg} 100 \mathrm{~g}^{-1}\right)$ followed by SA2 treated fruits $\left(195 \mathrm{mg} 100 \mathrm{~g}^{-1}\right)$. The ascorbic acid degrades during storage period due to oxidative reduction and activity of ascorbate oxidase. The markedly delayed ascorbic acid degradation in UT
+ SA2 and SA2 treated fruits could possibly be due to its restrained oxidation-induced breakdown and retarding ripening. Similar to these findings, Lu et al (2011) and Awad (2013) reported that SA delayed the decline of ascorbic acid content and prevented the destruction, so high contents of ascorbic acid in treated pineapple and peach fruits could improve the fruit quality.

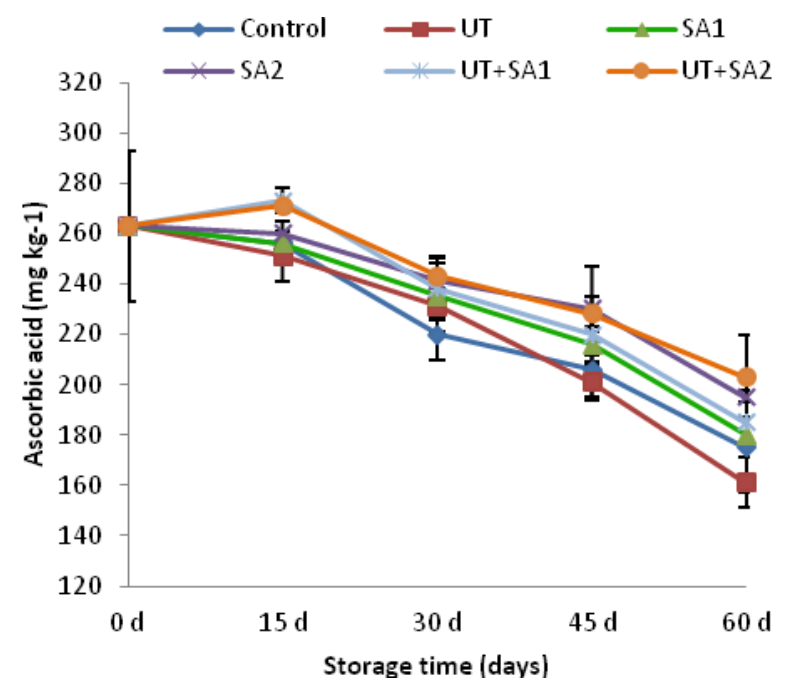

Figure 5

Effect of ultrasonic and salicylic acid treatments on ascorbic acid of nectarine fruit during storage

\section{Total flavonoid and total phenolic content}

In stone fruit the most abundant phenolics are flavonols and cinnamic acids, including chlorogenic and neochlorogenic acids (Ramina et al 2008). As shown in Figure 6 and Figure 7, at the beginning of the storage, the amounts of total flavonoid and phenolic contents

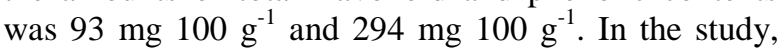
flavonoids followed a pattern very similar to that of phenolics, as also reported by Bal (2016) in SA treated peaches, the contents of total phenols and flavonoids in nectarine fruits fluctuated until $45^{\text {th }}$ day and then decreased in all treatment. Fruits treated with individual SA and combination of SA and UT had higher values of total flavonoid and total phenolic content than the untreated control fruits and UT alone. At the end of the storage, the highest both total flavonoid and total phenolic content were determined in UT + SA2 treated fruits $\left(108 \mathrm{mg} 100 \mathrm{~g}^{-1}\right.$ and $320 \mathrm{mg} 100 \mathrm{~g}^{-1}$, respectively). The results showed that the contents of total phenols and flavonoids of the nectarine fruits treated with UT + SA2 were higher than those treated with UT + SA1, which suggested that the effects of SA on total phenols and flavonoids contents of the nectarine fruits were concentration dependent. According to the results obtained that synergistic effects between salicylic acid and ultrasonic treatment were observed and combined treatment was more effective on enhancing total phenols and flavonoids. Similarly, Chen \& Zhu (2011) and Bal et al (2017) reported that ultrasonic treatment with other chemicals had synergistic effect that maintained the biochemical compound of fruits. Moreover, PerezBalibrea et al (2011) and Razavi et al (2018) have 
reported that the total phenols and flavonoids contents in broccoli sprouts and peaches were significantly increased by SA treatment.

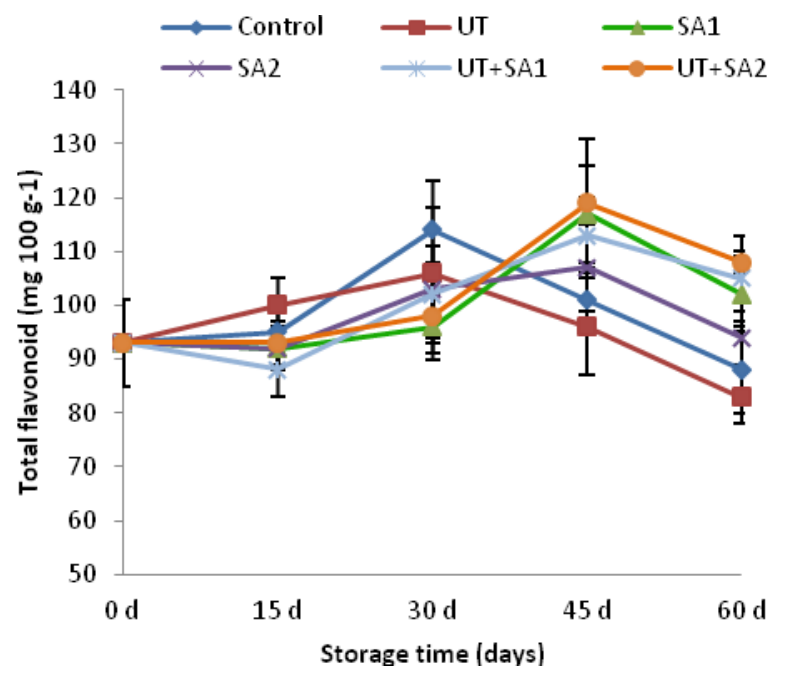

Figure 6

Effect of ultrasonic and salicylic acid treatments on total flavonoid of nectarine fruit during storage

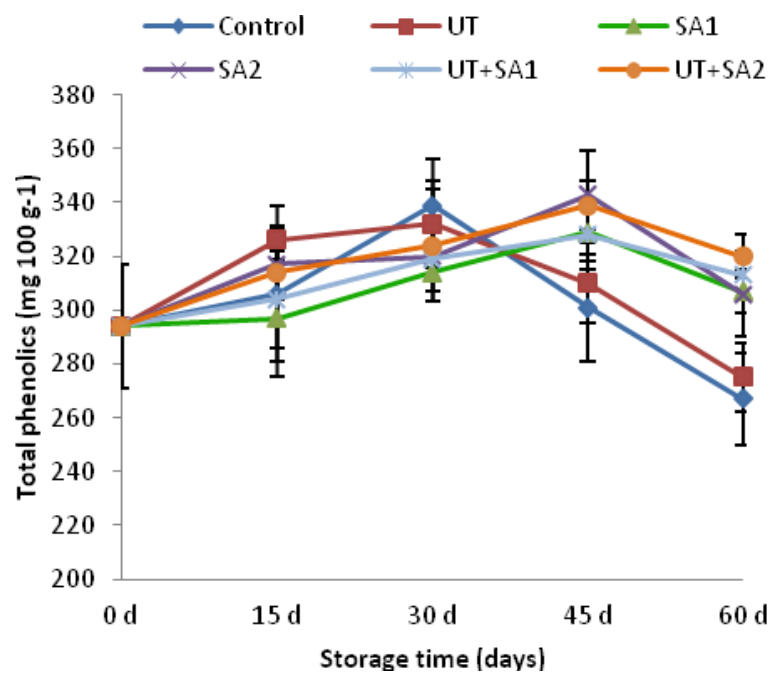

Figure 7

Effect of ultrasonic and salicylic acid treatments on total phenolics of nectarine fruit during storage

\section{Antioxidant content}

Nectarines are a good source of natural antioxidants, which provide protection against harmful reactive oxygen species and are associated with a lower incidence of chronic diseases (Shui\&Leong 2006). The antioxidant contents showed an initial increase, followed by a decrease during cold storage (Figure 8 ); this is consistent with previous studies (Xi et al 2017; Zhao et al 2018). The results of antioxidant activity showed that fruits treated with SA and UT and combination of SA and UT had higher antioxidant activity than control fruits after 60 days of storage. At the end of the storage, control fruits had the lowest antioxidant content (13 $\mu \mathrm{mol} \mathrm{g}{ }^{-1}$ ), while nectarine fruit treated with $\mathrm{UT}+\mathrm{SA} 2$ $\left(16.7 \mu \mathrm{mol} \mathrm{g}^{-1}\right)$ had the highest total phenolic content followed by UT + SA1 treatment $\left(16.5 \mu \mathrm{mol} \mathrm{g}{ }^{-1}\right)$. Ac- cordingly, SA molecules could have had more opportunities to penetrate the fruit tissue by ultrasonic application. Moreover, SA has been reported to regulate antioxidants and maintain dietary value during storage (Huang et al 2008). The regulation of antioxidants as a result of SA application is not clear. It may be due to activation of antioxidant system in response to signaling SA which results in systemic acquired resistance in the cells (Tareen et al 2012). Taking into account the change in UT + SA2 treatment, it could be confirmed that total phenolics, total flavonoids and ascorbic acid are the main compounds contributing to the antioxidant capacity of the nectarine fruits, in agreement with previous reports (Sayyari et al 2011; Gimenez et al 2014; Davarynejad et al 2015).

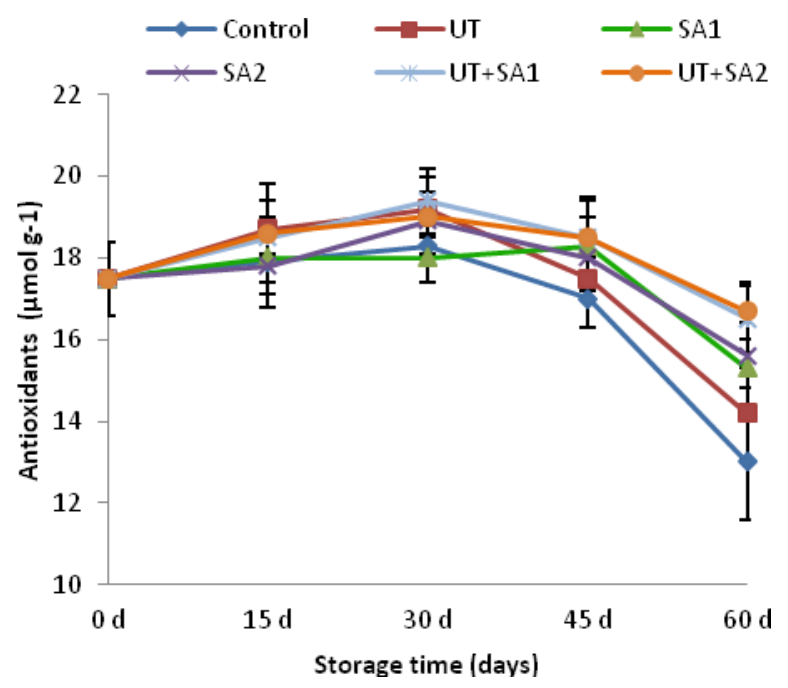

Figure 8

Effect of ultrasonic and salicylic acid treatments on antioxidants of nectarine fruit during storage

\section{Chilling Injury}

CI limits the storage life of peaches and nectarines under low temperature. It has been widely reported that the expression of CI symptoms, especially internal browning, develops faster and more intensely when susceptible fruit are stored at temperatures between 2.2 and $7.6^{\circ} \mathrm{C}$ than those stored at $0^{\circ} \mathrm{C}$ or below but above their freezing point (Lurie\&Crisosto 2005). As shown in Figure 9, no visible symptoms of CI were observed in the fruit when stored at $0^{\circ} \mathrm{C}$ for 30 days. In the present study, it was found that salicylic acid and combined treatment with ultrasonic treatment could effectively reduce $C I$ in nectarine fruit, and $2 \mathrm{mM}$ was the most effective concentration. CI symptoms, characterized by exocarp browning and flesh translucency, were observed the highest rate $(10-25 \%)$ in ultrasonic treated fruit and control fruit after 45 days of storage. At the end of the storage, the lowest CI rate was determined in $\mathrm{UT}+\mathrm{SA} 2$ treated fruits (1.1) followed by UT + SA2 and SA2 treated fruits (1.5), while the CI rate was determined in UT treated fruits (3.5) followed by control fruits (3). The lower CI symptoms in nectarines treated with SA alone and combined ultrasonic may be due to slower metabolic rates and retention of various 
bioactive compounds in fruits. Nowadays, it has been obvious that the CI symptoms are created due to the oxidative stress caused by overproduction of ROS and high values of antioxidant compounds inhibit ROS and contribute to reduce the CI symptoms (Yang et al 2011). Kang et al (2003) also reported that SA is involved in chilling tolerance through $\mathrm{H}_{2} \mathrm{O}_{2}$ metabolism mediation. Similar to previous studies (Cao et al 2010; Aghdam et al 2014; Khademi et al 2019), we found that SA treatment alleviated the CI symptoms of fruits.

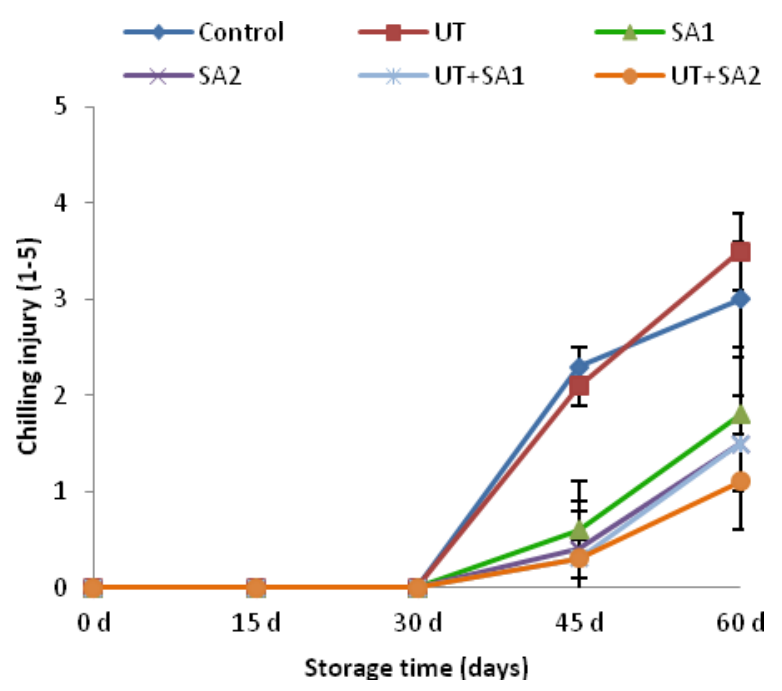

Figure 9

Effect of ultrasonic and salicylic acid treatments on chilling injury of nectarine fruit during storage

\section{Conclusion}

In conclusion, ultrasonic combined with SA treatment was more effective in alleviating CI and maintaining quality in nectarine fruit during the cold storage. However, ultrasonic treatment alone had similar effect to control treatment. Among the assayed doses (1 mM and $2 \mathrm{mM}$ ), the highest effect were found with SA at 2 $\mathrm{mM}$. The combination of $2 \mathrm{mM} \mathrm{SA}$ with ultrasonic treatment was especially successful in preserving quality attributes with a higher nutraceutical value through ascorbic acid, phenolic, flavonoid and antioxidant content. These results suggested that $2 \mathrm{mM} \mathrm{SA}$ with ultrasonic treatment might be a powerful strategy to enhance antioxidant potential and quality of nectarine fruits. In further research, the potential benefit of using the combination of ultrasonic technology and other safe chemicals as commercial postharvest treatments to maintain quality in nectarine fruit should be explored.

\section{References}

AOAC (1990). Official method 967.21. Vitamin C (ascorbic acid) in vitamin preparations and juices. (13th ed). Official methods of analysis Washington DC.

Asghari M, Aghdam MS (2010). Impact of salicylic acid on postharvest physiology of horticultural crops. Trends in Food Science and Technology 21:502-509.
Awad AM, Al-Qurashi AD, Elsayed MI (2013). Effect of prestorage salicylic acid and oxalic dipping on chilling injury and quality of 'Taify' pomegranates during cold storage. Journal of Food, Agriculture and Environment 11:117-122.

Bal E (2013). Effects of exogenous polyamine and ultrasound treatment to improve peach storability. Chilean Journal of Agricultural Research 73(4):435-440.

Bal E (2016). Effect of postharvest calcium chloride and ultrasound treatments on storage period and fruit quality of modified atmosphere packed fruit in plum cv. Santa Rosa. Fruit Science 1:12-18. (in Turkish)

Bal E, Kok D, Torcuk Aİ (2017). Postharvest putrescine and ultrasound treatments to improve quality and postharvest life of table grapes (Vitis vinifera L.) cv. Michele Palieri. Journal of Central European Agriculture 18(3):598-615.

Bal E (2018). Extension of the postharvest life of nectarine using modified atmosphere packaging and potassium permanganate treatment. Turkish Journal of Agriculture-Food Science and Tech . 6(10):13621369.

Brand-Williams W, Cuvelier ME, Berset C (1995). Use of free radical method to evaluate antioxidant activity. Lebensm Wiss Technol. 28:25-30.

Brown DS, Bringhurst RS, Crane JC, Hartmann HT, Webb AD, Beutel JA (1983). Fruit and Nut Crops. In: Scheuring, A.F., (Ed). A Guidebook to California Agriculture. University of California Press, Berkeley and Los Angeles. pp 135-162.

Candir E, Temizyürek E, Özdemir AE (2009). The effects of hot water dip treatments on the cold storage of Big Top nectarines. J Applied Botany Food Quality 82(2):136-140.

Cao S, Hu Z, Zheng Y, Lu B (2010). Synergistic effect of heat treatment and salicylic acid on alleviating internal browning in cold-stored peach fruit. Postharvest Biol. Technol. 58:93-97.

Celik M, Özdemir AE, Ertürk E (2006). Changes in some quality parameters if the perfect delight nectarine cultivar during cold storage and shelf Life. Turkish Journal of Agriculture and Forestry 30:253-260.

Chen Z, Zhu C (2011). Combined effects of aqueous chlorine dioxide and ultrasonic treatments on postharvest storage quality of plum fruit (Prunus salicina L.). Postharvest Biol. Technol. 61:117-23.

Chen Y, Jian Y, Yang S, Yang E, Yang B, Prasad KN (2012). Effects of ultrasonic treatment on pericarp browning of postharvest litchi fruit. Journal of Food Biochemistry 36:613-620.

Crisosto CH, Mitchel FG, Ju Z (1999). Susceptibility to chilling injury of peach, nectarine, and plum cultivars grown in California. Hort Science 34:11161118. 
Davarynejad GH, Zarei M, Nasrabadi ME, Ardakani E (2015). Effects of salicylic acid and putrescine on storability, quality attributes and antioxidant activity of plum cv. 'Santa Rosa'. J. Food Sci. Technol. 52(4):2053-2062.

Erbaş D, Onursal CE, Koyuncu MA (2015). Effect of postharvest salicylic acid treatments on cold storage of apricot cv. Aprikoz. Fruit Science 2(2):50-57. (in Turkish)

Ezzat A, Ammar A, Szabo Z, Holb IJ (2017). Salicylic acid treatment saves quality and enhances antioxidant properties of apricot fruit. Hort. Sci. (Prague) 44:73-81.

Gallo M, Ferrara L, Naviglio D (2018). Application of ultrasound in food science and technology: a perspective. Foods 7(10):164.

Gimenez MJ, Valverde JM, Valero D, Guillen F, Martínez-Romero D, Serrano M (2014). Quality and antioxidant properties on sweet cherries as affected by preharvest salicylic and acetylsalicylic acids treatments. Food Chem. 160:226-232.

Han T, Wang Y, Li L, Ge X (2003). Effect of exogenous salicylic acid on postharvest physiology of peaches. Acta Hort. 628:383-389.

Huang R, Xia R, Lu Y, Hu L, Xu Y (2008). Effect of pre-harvest salicylic acid spray treatment on postharvest antioxidant in the pulp and peel of 'Cara cara' navel orange (Citrus sinenisis L. Osbeck). J. Sci. Food Agric. 88:229-236.

Kader AA (2001). Postharvest technology of horticultural crops. University of California, Davis, 220231.

Kang GZ, Wang ZX, Sun GC (2003). Participation of $\mathrm{H}_{2} \mathrm{O}_{2}$ in enhancement of cold chilling by salicylic acid in banana seedlings. Acta Botanica Sinica 45:567-573.

Karen LBG (1991). Storage Conditions Fruits and Vegetables. In: "Postharvest Management of Commercial Horticultural Improving Postharvest Quality of Nectarine Fruits Crops". Co-op Extension, Kansas State University, Manhattan, Kansas, 1-7.

Khademi O, Ashtari M, Razavi F (2019). Effects of salicylic acid and ultrasound treatments on chilling injury control and quality preservation in banana fruit during cold storage. Scientia Hort. 249:334339.

Khan AS, Ahmed MJ, Zora S (2011). Increased ethylene biosynthesis elevates incidence of chilling injury in cold stored "Amber Jewel" Japanese plum (Prunus salicina Lindl.) during fruit ripening. Int. J. Food Sci. Technol. 46:642-650.

Lee SK, Kader AA (2000). Preharvest and postharvest factors influencing vitamin $\mathrm{C}$ content of horticultural crops. Postharvest Biol. Technol. 20:207-220.

Lu X, Sun D, Li Y, Shi W, Sun G (2011). Pre- and postharvest salicylic acid treatments alleviate inter- nal browning and maintain quality of winter pineapple fruit. Scientia Horticulturae 130:97-101.

Lurie S, Crisosto CH (2005). Chilling injury in peach and nectarine. Postharvest Biol. Technol. 37:195208.

Ozdemir AE, Erturk E, Celik M, Dilbaz R (2006). The cold storage of Venus nectarin cultivars. Journal of Tekirdag Agricultural Faculty 3(3):297-304. (in Turkish)

Perez-Balibrea S, Moreno DA, Garcia-Viguera C (2011). Genotypic effects on the phytochemical quality of seeds and sprouts from commercial broccoli cultivars. Food Chem. 125:348-354.

Ramina A, Tonutti P, McGlasson W (2008). Ripening, nutrition and postharvest physiology, In: Layne D.R., and D. Bassi (eds.) The peach: Botany, production and uses. CABI international, Wallingford, Oxfordshire, UK, pp. 634.

Sabir F (2017). Effect of salicylic acid treatments on quality changes of plum during the cold storage. Fruit Science 1(1):40-45. (in Turkish)

Sayyari M, Castillo S, Valero D, Diaz-Mula HM, Serrano M (2011). Acetyl salicylic acid alleviates chilling injury and maintains nutritive and bioactive compounds and antioxidant activity during postharvest storage of pomegranates. Postharvest Biol. Technol. 60:136-142.

Shui G, Leong LP (2006). Residue from star fruit as valuable source for functional food ingredients and antioxidant nutraceuticals. Food Chem. 97:277-284.

Slinkard K, Singleton VL (1977). Total phenol analysis: and comparison with manual methods. American Journal of Enology and Viticulture 28:49-55.

Srivastava MK, Dwivedi UN (2000). Delayed ripening of banana fruit by salicylic acid. Plant Science 158:87-96.

Supapvanich S, Promyou S (2013). Efficiency of salicylic acid application on postharvest perishable crops. In: Hayat, S., Alyemei, A. A. M. N. (Eds), Salicylic acid: Plant growth and development, Springer, New York USA. p. 339-355.

Tareen MJ, Abbasi NA, Hafiz IA (2012). Postharvest application of salicylic acid enhanced antioxidant enzyme activity and maintained quality of peach cv. 'Flordaking' fruit during storage. Scientia Hort. 142:221-228.

Wolucka BA, Goossens A, Inze D (2005). Methyl jasmonate stimulates the de novo biosynthesis of vitamin $\mathrm{C}$ in plant cell suspensions. J Exp Bot. 56:2527-2538.

Xi W, Lu J, Qun J, Jiao B (2017). Characterization of phenolic profile and antioxidant capacity of different fruit part from lemon (Citrus limon Burm.) cultivars. J. Food Sci. Technol. 54(5):1108-1118.

Veltman RH, Kho RM, van Schaik ACR, Sanders MG, Osterhaven J (2000). Ascorbic acid and tissue browning in pears (Pyrus communis L. cv. Rocha 
Bal / Selcuk J Agr Food Sci, (2020) 34 (1), 70-77

and Conference) under controlled atmosphere. Postharvest Biol. Technol. 19:129-137.

Yang ZF, Cao SF, Cai YT, Zheng YH (2011). Combination of salicylic acid and ultrasound to control postharvest blue mold caused by Penicillium expansum in peach fruit. Innovative Food Science and Emerging Tech. 12:310-314.

Yuting X, Lifen Z, Jianju Z, Jie S, Xingqian Y, Donghong $L$ (2013). Power ultrasound for the preservation of postharvest fruits and vegetables. International J. Agri. Biological Engineering 6(2):116-125.

Zhang Y, Chen K, Zhang S, Ferguson I (2003). The role of salicylic acid in postharvest ripening of kiwifruit. Postharvest Biol. Technol. 28:67-74.
Zhao Y, Feng Z, Li X (2007). Effect of ultrasonic and MA packaging method on quality and some physiological changes of fragrant pear. Journal of Xinjiang Agricultural University 30:61-63.

Zhao H, Shu C, Fan X, Cao J, Jiang W (2018). Nearfreezing temperature storage prolongs storage period and improves quality and antioxidant capacity of nectarines. Scientia Hort. 228:196-203.

Zheng Y, Zhang Q (2004). Effects of polyamines and salicylic acid on postharvest storage of 'Ponkan' mandarin. Acta Hort. 632:317-320.

Zhishen J, Mengcheng T, Jianming W (1999). The determination of flavonoid contents in mulberry and their scavenging effects on superoxide radicals. Food Chem. 64:555-559. 